\title{
Koruyucu ve Biyolojik Aileye Sahip Okul Öncesi Çocukların Ego Sağlamlıklarının Karşılaştırılması
}

\section{Comparison of Ego Resilience of Preschool Children with Foster and Biological Families}

\author{
Hüllya Gülay Ogelman 1* (D), Arzu Özyürek² \\ ${ }^{1}$ Sinop Üniversitesi, Eğitim Fakültesi, Temel Eğitim Bölümü, Sinop, Türkiye \\ ${ }^{2}$ Karabük Üniversitesi, Sağlık Bilimleri Fakültesi, Çocuk Gelişimi Bölümü, Karabük, Türkiye
}

\begin{abstract}
$\ddot{O} z$
Ego sağlamlığı, değişen koşullara uyum sağlayabilme yeteneği olarak ifade edilmektedir. Temelleri erken çocukluk yıllarında atılan ego sağlamlığı, genetik, çevresel ve bireysel faktörlerden etkilenmektedir. Bu çalışmada, koruyucu ve biyolojik aileye sahip okul öncesi yaş çocukların ego sağlamlıklarının incelenmesi amaçlanmıştır. Çalışma grubunu, koruyucu aileye $(\mathrm{n}=58)$ ve biyolojik aileye $(\mathrm{n}=68)$ sahip 5-6 yaşında 126 çocuk oluşturmuştur. Betimsel tarama modelindeki çalışmada, veriler Önder ve Gülay Ogelman (2011) tarafindan uyarlanan Çocuk Ego Sağlamlığı Ölçeği ile toplanmıştır. Eisenberg ve meslektaşları tarafindan Block'un Q-Sort yönteminden esinlenilerek 1996'da geliştirilen Çocuk Ego Sağlamlığı Ölçeği, çocukların psikolojik sağlamlığını ortaya çıkarmayı amaçlamaktadır. Ölçeğin anne-baba ve öğretmen formları bulunmaktadır. On iki maddeli ve 9'lu likert türündeki ölçek, tek boyuttan oluşmaktadır. Verilerin analizinde betimleyici istatistikler ve bağımsız örneklem t-Testi kullanılmıştır. Sonuç olarak, biyolojik aileye sahip çocukların ego sağlamlık düzeyleri koruyucu aileye sahip çocuklardan istatistiksel açıdan anlamlı düzeyde daha yüksek bulunmuştur. Bulgular alan yazın ışığında tartışılmıştır, erken yaşlarda ego sağlamlığının geliştirilmesi için öneriler geliştirilmiştir.
\end{abstract}

Anahtar Kelimeler: Ego Sağlamlığı, Okul Öncesi Dönem, Koruyucu Aile, Biyolojik Aile.

\begin{abstract}
Ego resilience is expressed as the ability to adapt to changing conditions. Ego resilience, the foundations of which were laid in early childhood, are influenced by genetic, environmental and individual factors. In this study, it is aimed to investigate the ego resilience of preschool children with a protective and biological family. The study group consisted of 126 children, 5-6 years old, with foster family $(\mathrm{n}=58)$ and biological family $(n=68)$. In the descriptive survey model, the data were collected with the Child Ego Resilience Scale adapted by Önder and Gülay Ogelman (2011). Descriptive statistics and independent sample t-Test were used to analyze the data. Eisenberg and colleagues adapted Block's Q-Sort method in 1996 to develop the Children's Ego Resiliency Scale, which is a measuring instrument that identifies the resiliency level of children. The scale has parent and teacher forms. The scale with twelve items and 9point likert consists of one dimension. As a result, ego resilience levels of children with biological families were found to be significantly higher than children with foster families. The findings were discussed according the literature, suggestions were developed to improve ego resilience at an early age.
\end{abstract}

Keywords: Ego Resiliency, Preschool Period, Foster Families, Biological Families. 


\section{Giriş}

Çocukların sağlıklı gelişimi, ailelerin birincil amacıdır ve öncelikle temel ihtiyaçları karşılamak olmak üzere çocukların gelişimleri aile ortamında desteklenir. Aile, çocuklara beslenme ve barınma gibi temel gereksinimler yanında sevgi ve güven gibi duygusal gereksinimlerin karşılanmasında da güvenli bir ortam sunar. Sağlıklı bir gelişim için çocukların güvenli ve kendilerini her yönden destekleyecek bir aile ortamına ihtiyacı vardır ve bu durum çocuğun yaşama uyumunun ön koşulu olarak görülebilir.

Bireylerin kendi benliği ve çevresi arasında dengeli ilişkiler kurabilmesi, bu ilişkiyi devam ettirebilmesi uyumlu bir yaşam için gereklidir. Uyum, yaşam boyu gerekli olan ve her insanda farklı düzeylerde bulunan önemli bir özelliktir (Liew, Cao, Hughes ve Deutz, 2018). Uyum sağlayabilme kapasitesi ise bireysel ve çevresel çeşitli faktörlerden etkilenebilmektedir. Uyum sağlama kapasitesi konusu bağlamında sıkça karşılaşılan kavramlardan biri, ego sağlamlığıdır. Uyum ile ego sağlamlığı kavramları birbirinin yerine ve bir arada kullanılabilmektedir (Brock ve Curby, 2016; Luthar, Crossman ve Small, 2015).

Ego sağlamlığı, değişen ya da farklılaşan çevresel koşullar sonucunda ortaya çıkabilecek stresle baş edebilme, var olan koşullara uyum sağlayabilme yeteneği olarak tanımlanabilmektedir (Block ve Block, 1980). Ego sağlamlığı üst düzeyde olan bir çocuk, yeni ve/veya beklenilmeyen durumlara rahatlıkla uyum sağlayabilir, stres karşısında kaygı düzeyini kontrol edebilir, kendisini yavaşlatacak ya da yanıltacak durumlara karşı direnebilir, etkili problem çözme stratejilerini kullanabilir. Ego sağlamlığı düzeyi düşük olan çocuklar ise değişen durumlar/koşullar karşısında rahatsız, kaygılı, üzgün ve endişelenmeye meyilli olabilir, travmatik deneyimler karşısında güçlü duramazlar (Block ve Block, 2006; Gjerde, Block ve Block, 1986).

Gelişimin temelleri yaşamın en erken yıllarında atılırken ego sağlamlığının temelleri de okul öncesi dönemde atılmaktadır (Taylor, Eisenberg, Spinrad ve Widaman, 2013). Bu nedenle, küçük çocukların stresle mücadele edebilmesi, değişikliklere başarılı bir şekilde kolaylıkla uyum sağlayabilmesi, sağlıklı bir gelişim için istenilen beceriler arasında yer almaktadır. Yapılan boylamsal araştırmalar, yaşamın ilk yıllarındaki ego sağlamlığının uzun süreli etkilerini ortaya koymaktadır. Örneğin, Taylor ve meslektaşları (2014b) 213 çocuğu 30 aylıktan 84 aylığa kadar izledikleri araştırmalarında korku, hayal kırıklığı ve ego sağlamlığı düzeylerinin sosyal yeterliğe etkisini izlemişlerdir. Araştırmanın bulguları, 84 aylıktaki ego sağlamlığının sosyal yeterliği yordadığını göstermiştir. Ego sağlamlığı düzeyi, korku, hayal kırıklığı ve uzun süreli olarak sosyal yeterlikler arasındaki ilişkilere aracılık etmiştir. Sonuçlar, öfke ve hayal kırıklığındaki bireysel farklılıkların, çocukların sosyal yeterliliği ile ilişkili olan ego-sağlamlığının gelişimine katkıda bulunabileceğini göstermiştir. Türkiye'de konu ile ilgili araştırmalar bulunmaktadır. Örnek olarak, 5-6 yaş grubundaki 77 çocuk ile yapılan bir çalışmada (Gülay Ogelman ve Önder, 2019), duygu düzenleme stratejilerinin psikolojik sağlamlığı yordayabildiği ortaya konulmuştur. Bir diğer çalışmaya (Bayındır, Balaban Dağal ve Önder, 2018) da, 60-72 aylık 288 çocuk ve anneleri katılmıştır. Araştırmanın bulgularına göre, okul öncesi dönem çocuklarda duygu düzenleme becerilerinin ego sağlamlık düzeyine göre farklılaştığı belirlenmiştir. Yaş ve cinsiyet değişkenlerinin çocukların ego sağlamlık ve duygu düzenleme becerileri üzerinde etkisi olmadığı bulunmuştur. Ayrıca cinsiyet, yaş ve duygu düzenleme becerisinin ego sağlamlık düzeyi üzerindeki birlikte etkisine bakıldığında, bu üç değişkenin birlikte ego sağlamlık düzeyi üzerinde etkili olmadığı belirlenmiştir. Genel olarak yaşamın ilk yıllarındaki ego sağlamlığının, çocukluk ve ergenlikteki akran ilişkilerindeki popülerlik ve sosyal yeterlikle ilişkili olduğu ifade edilmektedir (Cumberland-Li, Eisenberg ve Reiser, 2004; Swanson Valiente, Lemery-Chalfant ve O'Brien, 2011). Araştırmalardan elde edilen bulgular doğrultusunda, sağlıklı gelişim açısından ego sağlamlığının erken yaşlardan itibaren desteklenmesinin önem taşıdığı söylenebilir.

Ego sağlamlığının gelişiminde genetik, çevresel ve bireysel unsurların etkileri bulunmaktadır. Aile, ego sağlamlığını etkileyen çevresel değişkenler arasında önemli bir yere sahiptir (Gülay Ogelman, Seçer, Yalçın, Önder ve Erten Sarıkaya, 2015). Taylor ve meslektaşları (2014a), Amerika'da 153 çocuk ve ailesi ile yaptıkları çalışmada, çocukları 18 aylıktan 84 aylığa kadar gözlemlemişlerdir. Boylamsal araştırmanın sonucu, annebabalık davranışları ile seratonine ilişkin genetik çeşitliliğin, çocuklardaki ego-sağlamlığı düzeyini tek başına 
yordayabilen değişken olabileceğini ortaya koymuştur. Eisenberg ve meslektaşları (2004) mizaç, çaba gerektiren kontrol ve duygusallık gibi bazı bireysel özelliklerin ve ögrenilen baş etme becerilerinin ego sağlamlığını yordayabildiğini ifade etmişlerdir. Anne-babanın çocuğa sunduğu demokratik ortam, sıcak, ilgili ve anlayışa dayalı bir yaklaşım, güvenli bağlanma, olumlu kardeş ilişkileri gibi unsurlar ego sağlamlığını arttıran ve koruyan değişkenlerdir. Düşük sosyo-ekonomik düzey, anne-babanın hastalığı, işsizlik, boşanma, ebeveyn kaybı, olumsuz anne-baba davranışları gibi unsurlar ise ego sağlamlığına zarar verebilecek ve/veya azaltabilecektir (Reed Victor ve Stronge, 2002; Um, 2018). Çocuklar için ilk ve en önemli çevreyi oluşturan ailelerin çocuklarıyla ilişkilerini olumlu ya da olumsuz yönde etkileyebilecek faktörlerin, çocukların ego sağlamlığını da etkileyeceği açıktır.

Aile kavramı içerisinde son yıllarda yaygınlaşmaya devam eden koruyucu ailelik, korunmaya ihtiyacı olan çocuklara sağlanan bakım modelleri arasında yer almaktadır (Erdugan, 2019). Koruyucu ailelik, çeşitli sebeplerle biyolojik ailesi tarafindan bakılamayan çocukların, bakımlarını üstlenebilen birey veya ailelerin yanında, devlet denetimi altında kalmaları olarak ifade edilebilir (Daşbaş, 2015). Aile ve Sosyal Politikalar Bakanlığı'nın 2020 yılı verilere göre, Türkiye genelinde koruyucu aile sayısı 6159'a, hizmetten yararlandırılan çocuk sayısı ise 7483'e yükseltilmiştir (Illlere Göre Koruyucu Aile İstatistikleri, 2020). Türkiye'de koruyucu aile sayısı yıllara göre artış göstermiştir. Ancak alan yazın incelendiğinde, koruyucu ailelere yönelik araştırmaların oldukça yetersiz olduğu görülmektedir. Var olan çalışmalarda, koruyucu ailelik uygulamasının, koruyucu anne-babalar ve öz çocukları üzerindeki etkisi (Daşbaş, 2015), koruyucu ailelikle ilgili yaşam deneyimleri (Erdugan, 2019), koruyucu ailelik sisteminin değerlendirilmesi (Can, 2000; Karataş, 2007; Özbesler, 2009; Şahin Kaya, 2019; Tok, 1996) ve koruyucu anne-babaların empati düzeyinin (Yeşilkayalı, 2015) ele alındığı görülmektedir. Koruyucu veya biyolojik aile olma durumu, ailelerin çocuklara sundukları ortam, gelişimsel destek davranışları veya çocuk yetiştirme tutumları üzerinde etkili olabilir. Tüm bunlar da çocukların gelişimleri ve araştırmaya konu olan ego sağlamlığına etki edebilir. Yapılan alan yazın taramasında, biyolojik ve koruyucu aileye sahip okul öncesi dönem çocuklarının ego sağlamlıklarının ele alındığı bir çalışmaya rastlanmamıştır. Bu nedenle, bu araştırmanın konu ile ilgili sonraki çalışmalara rehberlik edebileceği düşünülmektedir. Koruyucu aileye sahip küçük çocukların duygusal gelişimleri başta olmak üzere çeşitli gelişim özelliklerinin ortaya konması, ailelere yapılabilecek çalışmalara rehberlik edebilir.

$\mathrm{Bu}$ araştırmanın amacı, koruyucu ve biyolojik aileye sahip okul öncesi dönem çocukların ego sağlamlıklarının ebeveyn bakış açısına göre incelenmesidir. Araştırmanın alt amaçları şu şekildedir:

- Koruyucu ve biyolojik aileye sahip çocukların ego sağlamlık düzeyi nasıldır?

- Anne bakış açısına göre koruyucu ve biyolojik aileye sahip çocukların ego sağlamlıkları arasında anlamlı bir fark var midır?

- Baba bakış açısına göre koruyucu ve biyolojik aileye sahip çocukların ego sağlamlıkları arasında anlamlı bir fark var midır?

\section{Yöntem}

\subsection{Araştırma Modeli}

$\mathrm{Bu}$ araştırmada, ilişkisel tarama yöntemi kullanılmıştır. İlişkisel tarama modelleri ise iki veya daha çok sayıdaki değişken arasında birlikte değişim varlığını ve/veya derecesini belirlemeyi amaçlayan araştırma modelleridir (Karasar, 2005). Çalışmada, koruyucu ve biyolojik aileye sahip olma değişkenleri arasında bir değişim olup olmadığı ve varsa bu ilişkinin derecesinin belirlenmesi amaçlanmıştır.

\section{2. Çalışma Grubu}

Araştırmada koruyucu aileye sahip 58 çocuk ve biyolojik aileye sahip 68 çocuk olmak üzere 5-6 yaşında 126 çocuk çalışma grubunu oluşturmuştur. Koruyucu aileye sahip çocukların 37'si $(\% 63,8) 5$ yaş, 21'i $(\% 36,2) 6$ 
yaşında, 38'i $(\% 65,5)$ kız ve 20'si (\%34,5) erkektir. Koruyucu aileye sahip çocuklardan 3'ü $(\% 5,2)$ 0-6 ay arasında, 8'i (\%13,8) 7-12 ay arasında, 20'si (\%34,5) 1-2 yıldır, 18'i (\%31) 3-4 yıldır, 9'u (\%15,5) doğumdan itibaren 5 yıldır koruyucu aile yanındadır. Biyolojik aileye sahip çocukların 31 'i $(\% 45,6) 5$ yaş, 37 'si $(\% 54,4)$ 6 yaşında, 31'i $(\% 45,6)$ kız ve 37'si $(\% 54,4)$ erkektir.

Çalışma grubundaki koruyucu ailelere Denizli Koruyucu Aile Derneği (DEKAD) aracılığı ile ulaşılmıştır. Gerek koruyucu aileler gerekse biyolojik aileler, Türkiye'nin farklı illerinde ikamet etmektedir. Aileler, veri toplama aracını Google Form uygulaması aracılığıyla online ortamda doldurmuşlardır.

\subsection{Veri Toplama Aracı}

Araştırma verilerinin toplanmasında, çocukların kişisel bilgilerinin sorgulandığı sorular ve çocukların ego sağlamlıklarının belirlenmesinde "Çocuk Ego Sağlamlığı Ölçeği” kullanılmıştır.

Çocuk Ego Să̆lamlı̆̆ı Ölçeği, Eisenberg ve meslektaşları tarafindan 1996 yılında, Block'un Q-Sort yönteminden uyarlanarak geliştirilmiştir. Ölçeğin anne-baba ve öğretmen formlan bulunmaktadır. On iki maddeli ve 9'lu likert türündeki ölçek, tek boyuttan oluşmaktadır. Ölçekten alınan puanlar arttıkça çocukların ego sağlamlık düzeyinin de arttığı, puanlar azaldıkça ego sağlamlık düzeyinin de azaldığı kabul edilmektedir. Türkçe'ye uyarlaması Önder ve Gülay Ogelman (2011) tarafından yapılan ölçeğin bu araştırma kapsamında hesaplanan Cronbach Alpha iç tutarlılık katsayısı, .74 olarak belirlenmiştir.

\subsection{Verilerin Toplanması ve Analizi}

Çalışma öncesi Karabük Üniversitesi Sosyal ve Beşerî Bilimler Araştırmaları Etik Kurulu'ndan etik uygunluk belgesi alınmıştır (27.05.2020 tarih, 2020/06 numaralı toplantı, Karar 12). Katılımcı onay formu ve ölçek maddeleri online ortamdan 5-6 yaş çocuğu bulunan koruyucu ve biyolojik ailelerle paylaşılmıştır. Ölçek formu anne veya babalar tarafindan doldurulmuştur.

Araştırmada, verilerin normal dağılıp dağılmadığını ortaya koymak için Skewness ve Kurtosis değerlerine bakılmıştır. Skewness değerinin -.947, Kurtosis değerinin ise 1.28 olduğu ortaya konulmuştur. Tabachnick ve Fidell (2013), Kurtosis ve Skewness değerlerinin -1.5 ile +1.5 arasında olmasının, veri setinin normal dağıldığının kabul edilebilmesi açısından yeterli bir ölçüt olduğunu ifade etmiştir. Verilerin analizinde betimleyici istatistikler ve bağımsız örneklem t-Testi kullanılmıştır.

\section{Bulgular}

Tablo 1'de koruyucu ve biyolojik aileye sahip çocukların ölçek puanları arasında fark olup olmadığına ilişkin betimleyici istatistik sonuçları verilmiştir.

Tablo 1.

Koruyucu ve biyolojik aileye sahip çocukların ölçek puanlarına ilişkin betimleyici istatistikler

\begin{tabular}{lllllll}
\hline Grup & N & Min. & Max. & $\bar{x}$ & S & Medyan \\
\hline Koruyucu Aileye Sahip Çocuk & 58 & 25,0 & 106,0 & 73,50 & 18,95 & 77,00 \\
Biyolojik Aileye Sahip Çocuk & 68 & 46,0 & 100,0 & 78,66 & 10,90 & 77,00 \\
\hline
\end{tabular}

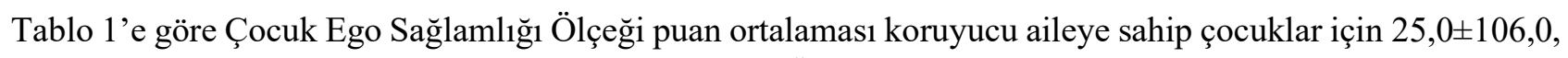
biyolojik aileye sahip çocuklar için 46,0 $\pm 100,0$ 'dır. Ölçekten alınabilecek en yüksek puanın 108 olduğu dikkate alındığında her iki grubun ölçek ortalama puanlarının ( $\bar{X}=73,50$ ve 78,66$)$ ortanın üzerinde olduğu görülmektedir. Ölçekten alınan puanları arttıkça çocukların ego sağlamlık düzeylerinin arttığı varsayıldığında, elde edilen bulguya göre her iki gruptaki çocukların ego sağlamlıklarının ortanın üzerinde iyi düzeyde olduğu söylenebilir. 
Tablo 2'de annelerin ve Tablo 3'te babaların bakış açısından çocukların ölçek puanları arasında fark olup olmadığına ilişkin analiz sonuçları verilmiştir.

Tablo 2.

Anne bakış açısına göre çocukların Çocuk Ego Sağlamlı̆̆ Ölçeği puanları t-testi sonuçları

\begin{tabular}{|c|c|c|c|c|c|c|c|}
\hline Grup & $N$ & $\overline{\mathrm{x}}$ & $\mathrm{S}$ & $S h_{\bar{x}}$ & $t$ & $\mathrm{Sd}$ & $p$ \\
\hline Koruyucu Aileye Sahip Çocuk & 50 & 74,06 & 19,04 & 2,69 & \multirow{2}{*}{$-1,780$} & \multirow{2}{*}{105} & \multirow{2}{*}{$0,001^{*}$} \\
\hline Biyolojik Aileye Sahip Çocuk & 57 & 79,37 & 11,25 & 1,49 & & & \\
\hline
\end{tabular}

$* \mathrm{p}<0,01$

Tablo 2'ye göre annelerin değerlendirmesi sonucunda koruyucu ve biyolojik aileye sahip çocukların Çocuk Ego Sağlamlığı Ölçeği puanları arasında istatistiksel açıdan anlamlı farklılık vardır $(p<0,01)$. Biyolojik aileye sahip çocukların Çocuk Ego Sağlamlığı Ölçeği puan ortalaması $(\bar{X}=79.37)$, koruyucu aileye sahip çocukların puan ortalamasından $(\overline{\mathrm{X}}=74.06)$ daha yüksektir.

Tablo 3 .

Baba bakış açısına göre çocukların Çocuk Ego Sağlamlı̆̆ Ölçeği puanları t-testi sonuçları

\begin{tabular}{llllllll}
\hline Grup & $N$ & $\overline{\mathrm{X}}$ & $\mathrm{S}$ & $\mathrm{Sh}_{\overline{\mathrm{x}}}$ & $t$ & $\mathrm{Sd}$ & $p$ \\
\hline Koruyucu Aileye Sahip Çocuk & 8 & 70,00 & 19,23 & 6,80 & \multirow{2}{*}{0,774} & \multirow{2}{*}{17} & $0,007^{*}$ \\
Biyolojik Aileye Sahip Çocuk & 11 & 75,00 & 8,38 & 2,53 & & & \\
\hline
\end{tabular}

*p $<0,01$

Tablo 3'e göre babaların değerlendirmesi sonucunda koruyucu ve biyolojik aileye sahip çocukların Çocuk Ego Sağlamlığı Ölçeği puanları arasında istatistiksel açıdan anlamlı farklılık vardır $(\mathrm{p}<0,01)$. Biyolojik aileye sahip çocukların Çocuk Ego Sağlamlığı Ölçeği puan ortalaması $(\overline{\mathrm{X}}=75,00)$, koruyucu aileye sahip çocukların puan ortalamasindan $(\overline{\mathrm{X}}=70,00)$ daha yüksektir.

Tablo 2 ve Tablo 3 birlikte değerlendirildiğinde, anne ve babaların bakış açısından biyolojik aileye sahip çocukların Çocuk Ego Sağlamlığı Ölçeği puanlarının koruyucu aileye sahip çocuklardan daha yüksek olduğu görülmektedir. Bunun yanında hem koruyucu hem de biyolojik aileden annelerin çocuklarını değerlendirmelerinde çocukların annelerinden aldığ Çocuk Ego Sağlamlığı Ölçeği puanlarının babalardan alınan puanlara göre daha yüksek olduğu görülmektedir.

\section{Tartıșma}

Araştırmada, çalışma grubundaki çocukların ego sağlamlıklarının ortanın üzerinde yüksek olduğu görülmüştür. Annelerin ve babaların değerlendirmesi ve genel olarak değerlendirme yapıldığında koruyucu ve biyolojik aileye sahip çocukların ego sağlamlıkları arasında biyolojik aileye sahip olan çocukların lehine anlamlı farklılık bulunmuştur. Koruyucu ailelere sahip olan çocukların ego sağlamlıklarının biyolojik aileye sahip akranlarına göre daha düşük düzeyde olduğu belirlenmiştir. Çocukların ego sağlamlıkları anne-babanın koruyucu veya biyolojik olmasından etkilenebileceği gibi anne ve babaların çocuklarını değerlendirirken takındıkları duygusal tavırla da ilişkili olabilir. Ayrıca annelerin çocuklarının ego sağlamlık düzeyini babalara göre daha yüksek düzeyde buldukları da görülmüştür.

Alan yazında konuyla ilgili bir çalışmasında Gülay Ogelman (2014), düşük sosyo-ekonomik düzeydeki ailelerden gelen 5-6 yaş grubundan 150 çocuğun ego sağlamlıklarını anne, baba ve öğretmen görüşlerine göre incelemiştir. Araştırmanın bulgularına göre anne, baba ve öğretmenlerin bakış açılarına göre çocukların ego sağlamlık düzeyleri farklılık göstermiş, en yüksek puan ortalamasının annelere, en düşük ortalamanın ise öğretmenlere ait olduğu belirlenmiştir (Gülay Ogelman, 2014). Bu araştırmada da annelerin değerlendirmesine göre çocukların Çocuk Ego Sağlamlığı Ölçeği puan ortalamaları, babaların değerlendirmesinden daha yüksek 
düzeydedir. Bu durum anne ve babaların çocuklarını farklı bakış açısıyla değerlendirdiklerini veya annelerin çocuklarına daha olumlu bir bakış açısıyla baktıklarını düşündürebilir.

Koruyucu aileye sahip çocukların ego sağlamlık düzeyinin biyolojik aileye sahip çocuklardan daha düşük olması, anne-babaların çocuklarına yönelik tutumlarına göre farklılık göstermiş olabilir. Daşbaş (2015) araştırmasında, koruyucu aileler çocukların davranışlarının zaman zaman zorlayabildiğini fakat buna rağmen koruyucu aileliğin güzel bir deneyim olduğunu ifade etmişlerdir. Bu araştırmada da, koruyucu ailelere sahip çocukların, biyolojik aileye sahip olan akranlarına göre birtakım davranış, uyum sorunları gösterebilecekleri, bu durumun da anne-babaların ego sağlamlığı değerlendirmelerine yansımış olabileceği düşünülebilir. Nitekim Cowen Wyman, Work ve Parker (1990), ego sağlamlığının sağlıklı aile ilişkilenin bir sonucu olarak geliştiğini ifade etmişlerdir. Ayrıca boşanma, maddi zorluklar, ebeveynlerin hastalığı gibi faktörlerin çocukların ego sağlamlığını olumsuz yönde etkileyebileceğini vurgulamışlardır. Bu çalışmada da, koruyucu aile yanında bulunan çocuklar, biyolojik ailelerindeki çeşitli olumsuz durumlardan (maddi yetersizlikler, anne ya da babadan çeşitli sebeplerle ayrı olma vb.) kaynaklı olarak devlet korunmasına verilmişlerdir. Dolayısıyla koruyucu aile yanındaki çocukların psikolojik sağlamlık düzeylerinin biyolojik ailelerindeki stresli durumlardan etkilenebileceği düşünülebilir. Rutter (1990) da ebeveyn-çocuk arasındaki olumlu ilişkinin çocukların ego sağlamlık düzeylerini arttırdığını, stresten koruyucu olduğunu, zorluklar ve problemler karşısında mücadeleci hale getirebildiğini ifade etmiştir. Bireyin psikolojik sağlamlığı yaşanması muhtemel olumsuz durumlarla başa çıkabilmesi ve uyum sağlayabilmesi açısından önemlidir. Aile üyelerinin olumlu desteği, psikolojik sağlamlığı artırmaktadır (Öngören ve Yılmaz, 2018). Bu çalı̧̧mada da, biyolojik aile yanındaki küçük çocukların psikolojik dayanıklılıklarının, koruyucu aile yanındakilere göre daha yüksek olduğu belirlenmiştir. Aile içindeki desteğin ve sağlıklı iletişimin, psikolojik sağlamlık üzerinde olumlu etkisi olduğu söylenebilir.

Koruyucu ailelik gönüllülük esasına dayandığı için ebeveynlerin ve biyolojik çocukların, aileye sonradan katılan çocuğu tanıma, onunla iletişim kurma, sevgi ve ilgi gösterme konusunda bilinçli, istekli ve özenli davrandıkları düşünülebilir. Erdugan (2019) tarafından koruyucu ailelerle yapılan nitel çalışmanın sonucunda, koruyucu aileler, bu durumun aile hayatına neşe, dinamizm, coşku getirdiği belirtilmiştir. Günlük yaşam içerisinde yardımlaşmanın arttığ ve bu durumun da sosyal destekte artışa yol açtı̆̆ ifade edilmiştir. Koruyucu aileye sahip olan çocuklar hem koruma altında oldukları hem de ilgili, sıcak bir aile ortamında yaşamlarına devam edebildikleri için avantajlı iken, biyolojik aileden uzakta olma ve onları belli koşullarda görüp yeniden koruyucu ailenin yanına dönme gibi durumlardan dolayı zaman zaman bocalayabilirler. Preston, Yates ve Moss (2012), bakım koşullarının değişmesi karşısında çocukların davranış değişiklikleri sergileyebileceğini ifade etmişlerdir. Örneklem grubundaki çocukların yaş grubunun küçük olduğu da göz önünde bulundurulunca, biyolojik aileden uzak olmanın, çocukların davranışlarına, tepkilerine dolayısıyla ego sağlamlığı düzeylerine yansımış olabileceğini düşündürebilir. İstanbul ve Ankara'daki çocuk yuvalarında kalan 6 yaş çocukları ile biyolojik aileyle yaşayan akranlarının sosyal beceriler açısından karşılaştırıldığı bir araştırmada (Gülay, 2004), biyolojik aileyle yaşayan çocukların, yuvadakilere göre sosyal becerilerini daha çok geliştirdikleri ortaya konulmuştur. Sosyal beceriler, psikolojik sağlamlığı doğrudan ve dolaylı olarak yordayabilen bir değişken olarak ifade edilmektedir (Jaureguizar, Garaigordobil ve Berneras, 2018). Alan yazındaki bilgiler ve araştırmalar, çocukların sosyal ve duygusal gelişim alanlarında sağliklı gelişim gösterebilmesi açısından ailelerin önemini ifade etmektedir.

Araştırmacılar (Schofield ve Beek, 2005; Sinclair ve Wilson, 2003), koruyucu ailelerdeki duyarl1, yakın ilişkilerin istikrarlı bir şekilde devam etmesinin çocukların ego sağlamlığını arttırabildiğini ifade etmişlerdir. Alvarado (2019), Amerika'da 5-15 yaş arasındaki evlat edinilmiş 6 çocukla yaptığı araştırmada, çocukların biyolojik olmayan ailesi ile geçirdiği süre arttıç̧a problemli davranışların azaldığını, kişilerarası ilişkilerin geliştiğini, sosyal becerilerin arttı̆̆ını belirlemiştir. Bu bağlamda, koruyucu aileliğin kurum bakımındaki çocuklar için önemi ve gerekliliği ortaya çıkmaktadır. 
Sonuç olarak çocukların ego sağlamlığının gelişmesinde aile ortamının önemi açıktır. Bu nedenle, çocukların aile ortamında yaşaması, ego sağlamlığı açısından olumlu etki oluşturmaktadır. Bu çalışmada, biyolojik aile yanında kalmanın çocukların ego sağlamlığını artırdığı görülse de koruyucu aile yanında kalan çocukların ego sağlamlıklarının da ortanın üzerinde olduğu dikkat çekmektedir. Buna göre, çocukların kurum bakımında kalması yerine koruyucu aileyle birlikte kalmalarının ego sağlamlığını olumlu etkileyeceği söylenebilir. Fakat bu öngörünün belirlenmesine yönelik bir çalışma yapılması, durumu daha somut şekilde ortaya koyacaktır. Benzer bir çalışmada, daha geniş örneklem grubu ve farklı değişkenlerle ilişkiler incelenebilir. Koruyucu ebeveynlerin tutumları, ego sağlamlık düzeyleri, iletişim becerileri gibi çeşitli değişkenler arası ilişkiler incelenebilir. Koruyucu aileye sahip çocukların gelişim alanlarına göre çeşitli becerileri, boylamsal olarak takip edilebilir. Koruyucu veya biyolojik ailelere yönelik eğitim programları hazırlanarak çocukların ego sağlamlığının geliştirilmesi konusunda aileler desteklenebilir. Türkiye'de koruyucu ailelik yaygınlaşırken, bu ailelerin, koruyucu aileye sahip çocukların gelişim düzeyleri, yaşadıkları sorunlar, uyum becerileri gibi farklı konularla ilgili çalışmaların yaygınlaştırılması gereklidir. Küçük çocukların psikolojik sağlamlığını etkileyen değişkenlere yönelik çalışmalar yaygınlaştırılabilir. Psikolojik sağlamlığı belirlemede, anne babanın yanı sıra çocukların görüşlerine başvurulan ölçme araçları geliştirilebilir. Annelerin ve babaların psikolojik sağlamlık üzerindeki bireysel ve ortak etkileri incelenebilir. Bu bağlamda araştırmanın, küçük çocukların ego sağlamlık düzeylerini ortaya koymak adına alan yazına katkılar sağladığı düşünülmektedir.

\section{Kaynakça}

Alvarado, A. E. (2019). The resilience within: perspectives from adults supporting foster children. (Unpublished doctoral dissertation). University of Northern Colorado, USA.

Bayındır, D, Balaban Dağal, A, ve Önder, A. (2018). Türkiye'deki 60-72 aylık çocuklarda duygu düzenleme becerilerinin ego sağlamlık düzeylerine göre incelenmesi. Adlyaman Üniversitesi Sosyal Bilimler Enstitüsü Dergisi, 29, 377-400.

Block J. H., \& Block J. (1980). The role of ego-control and ego-resiliency in the organization of behavior. In W. A. Collins (Ed.). Minnesota Symposia on Child Psychology. (Vol. 13, pp. 39-101). NJ: Erlbaum; Hillsdale.

Block J, \& Block J. H. (2006). Venturing a 30-year longitudinal study. American Psychologist, 61, 315-327.

Brock, L. L., \& Curby, T. W. (2016). The role of children's adaptability in classrooms characterized by low or high teacher emotional support consistency. School Psychology Review, 45, 209-225.

Can, Y. (2000). Koruyucu aile uygulaması: Ankara örneği. Yüksek Lisans Tezi. Hacettepe Üniversitesi, Sosyal Bilimler Enstitüsü, Ankara.

Cowen, E. L., Wyman, P. A., Work, W. C., \& Parker, G. R. (1990). The Rochester Child Resilience Project: Overview and summary of first year findings. Development and Psychopathology, 2, 193-212.

Cumberland-Li A, Eisenberg N, \& Reiser M. (2004). Relations of young children's agreeableness and resiliency to effortful control and impulsivity. Social Development, 13, 193-212.

Daşbaş, S. (2015). Koruyucu aile hizmetinin koruyucu aileler ve biyolojik çocukları üzerindeki etkisi. Toplum ve Sosyal Hizmet, 26(1), 65-87.

Eisenberg N., Spinrad T. L., Fabes R. A., Reiser M., Cumberland A., Shepard S. A., \& Thompson, M. (2004). The relations of effortful control and impulsivity to children's resiliency and adjustment. Child Development, 75, 25-46.

Erdugan, S. (2019). Koruyucu aile modelinde aile yaşam deneyimleri: Aile Sistemleri Teorisi temelinde niteliksel bir araştırma. Yüksek Lisans Tezi. Hacettepe Üniversitesi, Sosyal Bilimler Enstitüsü, Ankara.

Gjerde, P. F., Block, J., \& Block, J. H. (1986). Egocentrism and ego resiliency: Personality characteristics associated with perspectivetaking from early childhood to adolescence. Journal of Personality and Social Psychology, 51(2), 423-434.

Gülay, H. (2004). Korunmaya muhtaç ve ailesinin yanında yaşayan 6 yaşş̧ocuklarının sosyal becerilerinin karşılaştırılması. Yüksek Lisans Tezi. Hacettepe Üniversitesi, Sosyal Bilimler Enstitüsü, Ankara.

Gülay-Ogelman, H. (2014). Investigation of ego resiliency of preschool children according to opinions of mother, father, and teacher. European Journal of Research on Education, 2(2), 186-191. 
Gülay Ogelman, H., \& Önder, A. (2019). Emotional regulation strategies of 5-6-year-old children and their levels of resiliency, Early Child Development and Care, DOI: 10.1080/03004430.2019.1613650.

Gülay Ogelman, H., Seçer, Z., Yalçın, S. B., Önder, A., ve Erten Sarıkaya, H. (2015). Boşanma değişkenine göre okul öncesi dönem çocuklarının psikolojik sağlamlıklarının karşılaştırılması. Selçuk Üniversitesi Sosyal Bilimler Enstitü Dergisi, 33, 87-96.

İllere Göre Koruyucu Aile İstatistikleri (2020). https://koruyucuaile.ailevecalisma.gov.tr/illere-gore-koruyucu-aile-istatistikleri adresinden 23.06.2020 tarihinde erişilmiştir.

Jaureguizar, J., Garaigordobil, M., \& Berneras, E. (2018). Self-concept, social skills, and resilience as moderators of the relationship between stress and childhood depression. School Mental Health, 10, 488-499.

Karasar, N. (2005). Bilimsel araştırma yöntemi. Ankara: Nobel.

Karataş, K. (2007). Türkiye'de çocuk koruma sistemi ve koruyucu aile uygulamaları üzerine bir değerlendirme. Toplum ve Sosyal Hizmet, 18(2), 7-19.

Liew, J., Cao, Q., Hughes, J. N., \& Deutz, M. H. (2018). Academic resilience despite early academic adversity: a three-wave longitudinal study on regulation-related resiliency, interpersonal relationships, and achievement in first to third grade. Early Education and Development, 5, 762-779.

Luthar, S. S., Crossman, E. J., \& Small, P. J. (2015). Resilience and adversity In R.M. Lerner and M. E. Lamb (Eds.) Handbook of child psychology and developmental science. (7th Edition, Vol. III, pp. 247-286). New York: Wiley.

Önder, A., \& Gülay-Ogelman, H. (2011). The reliability-validity study for the Ego Resiliency Scale (Teacher-Mother-Father Forms) for children aged between 5 and 6, International Refereed Academic Social Sciences Journal, 2(1), 5-21.

Öngören, S., ve Yılmaz, E. (2018). Rastlantısal krizler. K. Tepeli ve E. Durualp (Ed.) Aile yaşam döngüsü, (ss. 287-328). Ankara: Hedef.

Özbesler, C. (2009). Koruyucu aile hizmetlerinde değerlendirme süreci. Aile ve Toplum, 16(16), 86-94.

Preston, S., Yates, K., \& Moss, M. (2012). Does emotional resilience enhance foster placement stability? A qualitative investigation. International Journal of Psychological Studies, 4(3), 153-166.

Reed-Victor, E., \& Stronge, J. H. (2002). Homeless students and resilience: Staff perspectives on individual and environmental factors, Journal of Children Poverty, 8(2),159-183.

Rutter, M. (1990). Psychosocial resilience and protective mechanisms. American Journal of Osthopsychiatry, 57(3), $316-331$.

Schofield, G., \& Beek, M. (2005). Risk and resilience in long-term foster-care. British Journal of Social Work, 35(8), $1283-1301$.

Sinclair, I., \& Wilson, K. (2003). Matches and mismatches: The contribution of carers and children to the success of foster placements. British Journal of Social Work, 33(7), 871-884.

Swanson J., Valiente C., Lemery-Chalfant K., \& O’Brien T. C. (2011). Predicting early adolescents' academic achievement, social competence, and physical health from parenting, ego resilience, and engagement coping. The Journal of Early Adolescence, 31, 548576 .

Şahin Kaya, Z. (2019). Uzmanların gözünden Türkiye'de koruyucu aile programı üzerine bir değerlendirme. Yayımlanmamış Yüksek Lisans Tezi. Hacettepe Üniversitesi, Sosyal Bilimler Enstitüsü, Ankara.

Tabachnick, B. G., \& Fidell, L. S. (2013). Using multivariate statistics. Boston: Pearson.

Taylor Z. E., Eisenberg N., Spinrad T. L., \& Widaman K. F. (2013). Longitudinal relations of intrusive parenting and effortful control to ego-resiliency during early childhood. Child Development, 84, 1145-1151.

Taylor Z. E., Eisenberg N., VanSchyndel, S. K., Eggum-Wilkens, N. D., Tracy L., \& Spinrad, T. L. (2014a). Children's Negative Emotions and Ego-Resiliency: Longitudinal Relations With Social Competence. Emotion, 14(2), 397-406.

Taylor, Z. E., Sulik, M. J., Eisenberg, N., Spinrad, T. L., Silva, K. M., Lemery-Chalfant, K., Stover, D. A., \& Verrellic, B. C. (2014b). Development of ego-resiliency: Relations to observed parenting and polymorphisms in the serotonin transporter gene during early childhood. Social Development, 23(3), 433-450.

Tok, Ö. (1996). Koruyucu aile hizmeti standartları ve ülkemizdeki durumu. Yayımlanmamış Yüksek Lisans Tezi. Hacettepe Üniversitesi, Sosyal Bilimler Enstitüsü, Ankara.

Um, B. (2018). Ego-resiliency, parenting style, and peer attachment as predictors of South Korean middle school students' school adjustment. Redfame: International Journal of Social Science Studies, 6(7), 14-30. 
Yeşilkayal1, H. D. (2015). Koruyucu aile bireylerinin sosyodemografik özellikleri ile empatik becerileri ve özgecilik durumlar arasındaki ilişkinin değerlendirilmesi. Yayımlanmamış Yüksek Lisans Tezi. Ankara Üniversitesi Sağlık Bilimleri Enstitüsü, Ankara. 